\begin{tabular}{|c|c|}
\hline \multirow{3}{*}{ 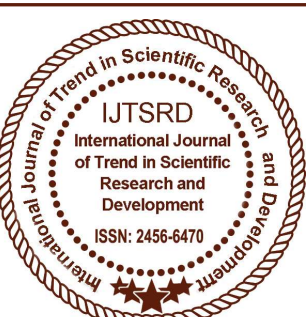 } & $\begin{array}{l}\text { International Journal of Trend in Scientific } \\
\text { Research and Development (IJTSRD) }\end{array}$ \\
\hline & International Open Access Journal \\
\hline & ISSN No: 2456 - 6470 | www.ijtsrd.com | Volume - 2 | Issue - 5 \\
\hline
\end{tabular}

\title{
Public Support and Facilitation of Co-operative-Aid to Women Empowerment:The Role of WDC Programme in Anambra State, Nigeria Onugu, Charles Uchenna ${ }^{1}$, Onuoha, Onyekachi Chibueze ${ }^{2}$ \\ ${ }^{1} \mathrm{Ph} . \mathrm{D},{ }^{2} \mathrm{M} . \mathrm{Sc}$, Department of Co-operative Economics and Management \\ Nnamdi Azikiwe University, Awka, Anambra State, Nigeria
}

\section{ABSTRACT}

The thrust of the study is to examine public support and facilitation of co-operative aid to women empowerment with focus on Women Development Centre (WDC) in Anambra State. Thirty (30) members of Women Co-operative Societies in WDC and 24 members of staff in WDC were randomly selected for the study. Data were collected through the use of two sets of structured questionnaires for the women co-operative members and staff of WDC. The data collected were analyzed using descriptive statistics comprising mean, simple and multiple percentages, while the hypotheses were tested using chi-square and f-test. The major findings include that the major roles co-operative play in women empowerment are facilitating skills development, assisting in training of members, easy access to credit facilities and provision of employment opportunities. Extension services are facilitated to women cooperative in the form of agro-extension services, management and financial advice as well as accounting and record keeping education. The research work proved that WDC programmes are instrumental to women's educational advancement and that saving level and access to credit of women increased when they joined women co-operative. The study also identified challenges to effective implementation of WDC programmes and possible remedies to them so as to strengthen the developmental role of WDC in Anambra state.

Keywords: Public Support, Co-operative, Women, Empowerment, WDC

\section{INTRODUCTION}

In most developing nations, women have limited access to socio-economic rights and privileges, (Esere, 2001). Nigerian women are perceived as household property that join hand in economic activities of their families with regard to exchange in marriage, participation in agricultural activities and other areas that yield money. Women thus manage the home and at the same time, participate with their male counterpart in developing the economy of the nation (Ekesionye and Okolo, 2012). According to Borode (2001), women especially the illiterate and rural women in the developing countries tend to be seriously affected by the waves of ignorance and poverty.

Akosile (2007) argued that if women are adequately empowered in Nigeria, the country will experience unprecedented development. They have the potential to turn an ailing economy around, at the family, local, state or national levels, through their in-bred economic strength, organizational skills and focus. Yahaya and Lasiele (1999) reiterated that women can be described as an indispensable group in the development of any nation. They further stated that apart from their numerical strength, women have great potentials necessary to evolve a new economic order, to accelerate social and political development and consequently transform the societies into a better one.

The need to include women as partners in development has necessitated the introduction of terms such as "gender sensitivity" in which some public offices and assignments are allocated to women and the greater the number of women in such positions the greater sensitivity the leadership is deemed to express (Agu, 2007).

Public support on women empowerment has been on the increase. Various leaderships now advocate for better representation of women at the helm of affairs. The wife of the president of Nigerian, Mrs. Patience 
Jonathan, had also done a massive campaign on women proper representation all over the country.

Co-operatives which are established by like-minded persons to pursue mutually beneficial economic interest have been identified by Esere (2001) to have the capacity of bringing down cost of lending, reducing over dues and aiding those who need credit mostly the rural poor.

In recent times, most governments in Nigeria; at the local, state and national levels, through institutional creation of women development ministries, development centres and also activitiesof the first ladies have been in the vanguard of women empowerment, particularly through the co-operative platform.

\section{STATEMENT OF THE PROBLEM}

Nigerian women have limited access to socioeconomic rights and privileges. They enjoy low social status and are encumbered by harmful traditional practices to exhibit their potentials (FGN, 1996). Nigerian women have been contributing their quota to the development of the nation, however, their potentials have not been fully tapped due to some constraints. Yahaya and Lasiele (1999) perceived the Nigerian women to be relegated to the background as they lack the educational, economic and political power necessary to actualize their innate potentials. Despite the contributions of women in the agricultural sector, their roles in promoting economic growth and social stability continues to be inadequately recognized and have been undervalued ( Onugu, 2006). Considering the potentials of women in Nigeria quest for development, various efforts have been done by government to ensure that they are empowered. The Women Development Centre (WDC), an agency of the Ministry of Women Affairs and Social Development of Anambra state government has also been in place to ensure same and facilitate co-operative aid. This study is challenged therefore to enquire if indeed:

$>$ Women are empowered through co-operative-aid in the WDC in Anambra state,

$>$ WDC has aided co-operative in exposing and enhancing women in education,

$>$ Co-operative activities in WDC indeed facilitated women access to extension services,

$>$ WDC aided co-operative activities to induce improved savings among women,
WDC has aided co-operative activities in enhancing women access to credit facilities,

$>$ There are challenges militating against the effectiveness of WDC programme and ways of addressing them.

\section{OBJECTIVE OF THE STUDY}

The main objective of the study is to examine public support and facilitation of co-operative aid to women empowerment through Women Development Centre (WDC). Specifically the study is designed to:

1. Ascertain the activities of WDC in Anambra state.

2. Identify the role of co-operatives towards women empowerment in the WDC programme.

3. Investigate if co-operative activities in the WDC have exposed and enhanced women in education.

4. Determine if co-operative activities in WDC have facilitated women access to extension services.

5. Examine if co-operative activities in WDC have induced improved savings among women.

6. Determine if co-operative activities in WDC have facilitated women access to credit facilities.

7. Identify challenges to the effectiveness of WDC programme and ways of addressing them.

\section{HYPOTHESES}

$\mathrm{Ho}_{1}$ - Co-operative members to a significant level do not perceive WDC programme as instrumental to their educational advancement.

$\mathrm{Ho}_{2}-\mathrm{Co}$-operative members to a significant level do not regularly access extension services in the WDC programme

$\mathrm{Ho}_{3}$-There is no significant difference in the savings level of co-operative members before and after joining the WDC programme.

$\mathrm{Ho}_{4}$-There is no significant difference in the amount of credit accessed by co-operative members before and after joining the WDC programme.

\section{LITERATURE REVIEW}

\section{Concept of Women Empowerment}

Empowerment was viewed by Longwe (1997) to involve the transformation of patriarchal societies through a process of enlightenment and collective organization. Empowerment in this context means assistance which may be in the form of cash, materials or training provided to women to enable them influence changes in their socio-economic status and to use their improved capacities to harness their hidden potentials. 
Women empowerment in the words of Yahaya and Lasiele (1999) can be described as the provision of adequate opportunity to women to develop their potentials and contribute to the development of the nation in particular and to the world in general. Women empowerment was seen by Agu (2007), as the capacity of women to increase their self-reliant strategies through the inducement of education.

Women empowerment is the provision of conducive, environment or opportunity to women to contribute their quota to the social, political and economic development of a nation. Borode (2011) explained women empowerment as the process of improving the human capital among women for effective participation in sustainable development activities. This will make women become makers of development and not just receivers or objects of it.

\section{The Economic Status of Women in Nigeria}

The status and role of women are usually linked specifically to their positions being a woman. A woman usually lives with a man who is her husband or her father and she is mostly tied to her dwelling and to her household activities (Oshodi and Imasuen 2009). However, Borode (2009) noted that participation in income generating activities is a vital interest to women throughout the developing world. Women often participate in those activities which they feel bring increased income which they could use to supplement whatever is available or brought in by their spouses. He also indicated that in some cases, women contribute greatly to the family and to the economy of any country through food production. Ekesionye and Okolo (2012) affirmed that the modern day Nigerian women take part in important economic activities to the benefit of their families and the entire nation.

\section{The Role of Co-operative Societies in Women Empowerment}

Co-operative is defined as an autonomous association of persons united voluntarily to meet their common economic, social and cultural needs and aspirations through a jointly owned and democratically controlled enterprise (ICA, 1995). Co-operative is a medium through which services like provision of farm inputs, farm implements, farm mechanization, agricultural loans, agricultural extension, members' education, marketing of members' farm produce and other economic activities and services are rendered to members.
According to Chukwu (1990), the members join the co-operative because it promises to be the most effective instrument towards gainingincreased income. Oyeniyi (2005) summarized the benefit of cooperatives as improved possibility of investment, social benefit, educational benefit, employment generation, self-help and improved standard of living.

The fact that co-operative groups are now being formed by women, who by nature are thrifty and honest, makes everyone see co-operatives as having a great future. The progress achieved by women through co-operatives in South-south states of Nigeria is heartening (National Gender Policy, 2006). In order to ensure sustainable women participation, the Women Development Centre as an important agency in the Ministry of Women Affairs and Social Development in Anambra state has made concerted efforts to ensure that women are adequately empowered.

\section{METHODOLOGY}

The study adopted survey research method for the collection of data and was carried out among cooperative societies under the Women Development Centre (WDC) located in Anambra north geo-political zone of Anambra State. Women Development Centre (WDC) is under the Ministry of Women Affairs and Social Development.

The population of the study consisted of all women co-operative societies in two Local Government Areas (Awka South Local Government and in Njikoka Local Government), out of the seven (7) LGAs in Anambra north geo-political zones under the Women Development Centre (WDC) and also the staff members of WDC. The total number of women cooperative societies is 24 and their total membership is 300 , while the number of staff in WDC is 30 .

A systematic random sampling technique was used to select 30 respondents from $\operatorname{six}(6)$ co-operative societies within Awka South Local Government and Njikola Local Government as well as 24 members of staff representing $10 \%$ and $80 \%$ respectively. The Major instrument for data collection in this study was 2 sets of structured questionnaire designed respectively for the women co-operative members and members of staff of WDC. The use of the aforementioned LGAs for the study was purposive since majority of the co-operative societies involved 
International Journal of Trend in Scientific Research and Development (IJTSRD) ISSN: 2456-6470

with the WDC are located there. This is as a result of their proximity to Awka, where WDC is situated. of data collected and then deployed chi-square and Ftest statistics in the test of the hypotheses.

The researchers used descriptive statistics involving mean, simple and multiple percentages in the analysis

\section{RESULTS AND DISCUSSIONS}

Socio-economic Characteristics of Co-operative members and WDC Staff

Table 1: Distribution of Respondents on Socio-economic Characteristics

\begin{tabular}{|c|c|c|c|c|}
\hline \multirow{2}{*}{$\begin{array}{l}\text { Socio-economic } \\
\text { Characteristics }\end{array}$} & \multicolumn{2}{|c|}{ Co-operative members } & \multicolumn{2}{|c|}{ WDC Staff } \\
\hline & Frequency $(\mathrm{N}=30)$ & Percentage (\%) & Frequency $(\mathrm{N}=24)$ & Percentage (\%) \\
\hline Age & & & & \\
\hline Less than 31 years & & & & 13 \\
\hline $31-50$ years & 30 & 100 & & 58 \\
\hline 51 years and above & & & & 29 \\
\hline Marital Status & Frequency $(N=30$ & Percentage (\%) & Frequency $(N=24)$ & Percentage (\%) \\
\hline Single & 3 & 10 & & 13 \\
\hline Married & 25 & 83 & 21 & 87 \\
\hline Divorced & & 7 & 8 & - \\
\hline Family Size & Frequency $(N=30$, & Percentage (\%) & Frequency $(N=24)$ & Percentage (\%) \\
\hline Less than 4 & 9 & Sedil 30 aाt & 11 & 46 \\
\hline $4-6$ & $8 \quad 10$ & VelO33nen & 8 & B \\
\hline $7-9$ & 0 & 30 & 50 & 21 \\
\hline $10-11$ & 2 & & $0 \%$ & - \\
\hline Qualification & Frequency $(N=30$, & Percentage (\%) & Frequency $(N=24)$ & Percentage (\%) \\
\hline FSLC & 19 & 63 & Pra & \\
\hline WAEC/GCE & 9 & 30 & 2 & 8 \\
\hline OND/NCE & 2 & $\frac{7}{7}$ & 7 & 29 \\
\hline $\mathrm{BSc} / \mathrm{HND}$ & - & - & 11 & 46 \\
\hline MSc/Ph.D & - & - & 4 & 17 \\
\hline
\end{tabular}

Source: Field Survey, October 2012.

The table above revealed that all the respondents from co-operatives was between the ages of 31 and 50 years while $58 \%$ of the respondents fall within the age range which represents the average age range. Both members of staff and members were more of married women. The family size of each household were evenly spread however, it is evident that the average Nigerian woman has become conscious of the fact that many children signify huge responsibility, the table showed that an average woman had between 1 and 6 family members. Also the members of staff of WDC are highly learned as many of them had tertiary institution's qualifications while the members are mainly first school living certificate holders and WAEC holders. None of the members had a university degree. 
International Journal of Trend in Scientific Research and Development (IJTSRD) ISSN: 2456-6470 Activities of WDC

Table 2: Distribution of Respondents on the Activities of WDC

\begin{tabular}{|c|c|c|}
\hline Activities & Frequency $(N)=24)$ & *Percentage (\%) \\
\hline Registration of Co- operative in Anambra State & 10 & 42 \\
\hline Granting loans and credit facilities to women co-operatives & 23 & 96 \\
\hline Providing Agro-Extension services to women co-operatives & 22 & 92 \\
\hline Providing education facilities to women co-operative societies & 15 & 42 \\
\hline Educating women on family planning & 5 & 21 \\
\hline Educating women on Health Issues & 6 & 25 \\
\hline Educating women on quality nutrition & 8 & 33 \\
\hline Skills development (craft, sewing hair making, baking etc) & 24 & 100 \\
\hline Creating Employment & 21 & 88 \\
\hline
\end{tabular}

*Multiple Responses

Source: Field Survey, October 2012.

Table 2showed that the major services of women development centre (WDC) are skills development(100\%); granting loans and credit facilities to women co-operatives $(96 \%)$; providing agro-extension services to women co-operative $(92 \%)$; and creating employment $(88 \%)$.

Role of Co-operative societies in WDC Programme

Table 3: Distribution of Respondents on the Role of Co-operatives in WDC Programme

\begin{tabular}{|c|c|c|}
\hline Roles & Frequency $(\mathrm{N}=24)$ & *Percentage (\%) \\
\hline Assisting in the training of members & 24 & 100 \\
\hline Provision of employment opportunities & 15 & 63 \\
\hline Educating members on health care & 7 & 29 \\
\hline Easy access to credit facilities & 20 & 83 \\
\hline Savings mobilization & 10 & 42 \\
\hline Educating members on quality nutrition & $\mathrm{C}$ and & 3 \\
\hline Educating members on family planning & 11 & 46 \\
\hline Facilitating skills development & 24 & 100 \\
\hline Management/entrepreneurship training & 23 & 96 \\
\hline Facilitating Networking/Mentoring & $56-6473$ & 54 \\
\hline
\end{tabular}

*Multiple Responses

Source: Field Survey, October 2012.

Table 3 above revealed that the major roles of co-operative in enhancing empowerment of women are facilitating skills development (100\%); assisting in the training of members $(100 \%)$; management and entrepreneurship training (96\%); easy access to credit facilities $(83 \%)$; provision of employment opportunity (63\%); and facilitating networking/mentoring of members $(54 \%)$.

\section{Facilitation of Educational Exposure}

Table 4: Distribution of Respondents on Educational Programmes Provided to Members \begin{tabular}{|l|l|l|}
\hline Educational Programme & Frequency $(\mathrm{N}=54)$ & *Percentage (\%) \\
\hline
\end{tabular}

\begin{tabular}{|c|c|c|}
\hline Seminar & 54 & 100 \\
\hline Workshops & 50 & 93 \\
\hline Conferences & 42 & 78 \\
\hline Certificate Courses & 15 & 28 \\
\hline Apprenticeship & 38 & 70 \\
\hline Executive Attachment & 2 & 4 \\
\hline Exchange programme & 0 & 0 \\
\hline Tour/Excursions & 0 & 0 \\
\hline
\end{tabular}

*Multiple Responses

Source: Field Survey, October 2012. 
International Journal of Trend in Scientific Research and Development (IJTSRD) ISSN: 2456-6470

Both respondents (co-operative members and WDC staff) were multiply asked the educational programmes WDC exposes women to. The result from table 4 showed that the major educational programmes the cooperative members were exposed to are seminar (100\%); workshops (93\%); conferences $(78 \%)$; and apprenticeship (70\%).

\section{WDC Provision of Extension Services}

Table5: Distribution of Respondents on the Facilitation of Extension Services

\begin{tabular}{|c|c|c|}
\hline Extension Services & Frequency $(\boldsymbol{N}=30)$ & Percentage \% \\
\hline Health Education & 5 & 17 \\
\hline Home Nutrition & 6 & 20 \\
\hline Family Planning & 3 & 10 \\
\hline Financial Advice & 18 & 60 \\
\hline Managerial Advice & 20 & 67 \\
\hline Accounting/Record Keeping & 20 & 67 \\
\hline Agro-extension services & 30 & 100 \\
\hline Networking/Mentoring services & 0 & 0 \\
\hline Marketing/ Processing support & 5 & 21 \\
\hline
\end{tabular}

\section{Multiple Responses}

Source: Field Survey, October 2012.

Table5 showed that the main extension services facilitated by WDC through co-operatives are Agro-extension services (100\%); managerial advice (67\%); accounting/Record keeping (67\%); financial advice (60\%).

\section{Regularity of Extension Services}

Table 6: Distribution of Respondents on How Regular Extension Services are provided to Women Cooperatives

\begin{tabular}{|c|c|c|c|c|c|c|c|}
\hline Extension Services & $\begin{array}{l}\text { Very (5) } \\
\text { Regular }\end{array}$ & $\begin{array}{l}\text { (4) } \\
\text { regular }\end{array}$ & $\begin{array}{l}\text { (3) Not } \\
\text { Regular }\end{array}$ & $\begin{array}{c}\text { (2) } \\
\text { Seldom }\end{array}$ & $\begin{array}{l}\text { (1) Not } \\
\text { at all }\end{array}$ & $\begin{array}{c}\text { Mean } \\
(x)\end{array}$ & Remarks \\
\hline Health Education & 0 & 0 sea & 5 h 2 n & 20 & 50 & 2 & Seldom \\
\hline Home Nutrition & 0 & 0 & 9 & 18 & 3 & 2.2 & Seldom \\
\hline Agro-extension services & 28 & 2 & An & 0 & 0 & 4.9 & Very Regular \\
\hline Financial advice & 10 & 15 & 5 & 10 & 0 & 4.8 & Very Regular \\
\hline Managerial Advice & 17 & 2 & 6 & & 0 & 4.2 & Regular \\
\hline Family planning & 0 & 0 & 8 & 40 & 18 & 1.6 & Seldom \\
\hline Basic Accounting/record keeping & & 5 & 2 & 10 & 0 & 4.7 & Very Regular \\
\hline Networking/ Monitoring services & 0 & & & 11 & 14 & 1.7 & Seldom \\
\hline Marketing/processing support & 4 & 0 & 0 & 7 & 23 & 1.2 & Not at all \\
\hline
\end{tabular}

Source: Field Survey, October 2012.

Table 6 above confirmed that Agro-extension services; financial advice; and, basic accounting/record keeping were very regular extension services provided to women co-operatives. Managerial advice was regular, but health education; home nutrition; family planning; and networking/monitoring services were seldom provided while marketing/ processing support was not provided at all.

\section{Facilitation of Savings Improvement}

Table 7: Distribution of Respondents on Monthly Savings Before and After Joining WDC Programme

\begin{tabular}{|c|c|c|c|c|}
\hline \multirow{2}{*}{ Saving Range (*)) } & \multicolumn{2}{|c|}{ Before Joining WDC } & \multicolumn{2}{c|}{ After Joining WDC } \\
\cline { 2 - 5 } & Frequency $(\mathbf{N}=30)$ & Percentage (\%) & Frequency (N=30) & Percentage (\%) \\
\hline 1000 and less & 6 & 20 & 0 & - \\
\hline $1001-3000$ & 17 & 57 & 7 & 23 \\
\hline $3001-5000$ & 5 & 16 & 5 & 33 \\
\hline $5001-7000$ & 2 & 7 & 5 & 17 \\
\hline $7001-9000$ & - & - & 3 & 10 \\
\hline 9001 and above & - & - & & \\
\hline
\end{tabular}

Source: Field Survey, October 2012. 
International Journal of Trend in Scientific Research and Development (IJTSRD) ISSN: 2456-6470

Table 7showed that before joining WDC, majority of the women saved between $\$ 1001$ and $¥ 3000$ but after joining WDC savings increased and the women saved more.

\section{Facilitation of Credit Access}

Table 8: Distribution of Respondents on the Total Credit (loan) Before and After Joining WDC programme.

\begin{tabular}{|c|c|c|c|c|}
\hline \multirow{2}{*}{ Credit Range (1) } & \multicolumn{2}{|c|}{ Before Joining WDC } & \multicolumn{2}{c|}{ After Joining WDC } \\
\cline { 2 - 5 } & Frequency $(\mathbf{N}=30)$ & Percentage (\%) & Frequency $(\mathbf{N}=30)$ & Percentage (\%) \\
\hline 50,000 and less & 18 & 60 & - & - \\
\hline $51,000-100,000$ & 7 & 23 & 3 & 10 \\
\hline $101,000-150,000$ & 5 & 17 & 5 & 17 \\
\hline $151,000-200,000$ & - & - & 5 & 17 \\
\hline $201,000-250,000$ & - & - & 10 & 33 \\
\hline $251,000-300,000$ & - & - & 5 & 6 \\
\hline 301,00 and above & - & - & 2 & 17 \\
\hline
\end{tabular}

Source: Field Survey, October 2012.

Table7revealed that the bulk of loan accessed before joining WDC were mainly $\$ 50,000$ and less while after joining WDC, most credit accessed were from N201, 000 and above. This implies that WDC actually facilitate far more credit to women co-operatives than those who haven't joined.

Challenges of Facilitating Women Empowerment under WDC Programme

Table 9: Distribution of Respondents on Challenges of Facilitating Women Empowerment under WDC Programme

\begin{tabular}{|c|c|c|c|c|}
\hline \multirow[b]{2}{*}{ Challenges } & \multicolumn{2}{|c|}{ Co-operative Members } & \multicolumn{2}{|c|}{ WDC Staff } \\
\hline & Frequency $(N=30)$ & *Percentage (\%) & $\begin{array}{l}\text { Frequency } \\
\qquad(N=24\end{array}$ & *Percentage (\%) \\
\hline Funding and Finance & 30 & 100 & 10 & 41 \\
\hline Sustaining training & 20 esea & $\operatorname{coh} 267$ & 20 & 83 \\
\hline Sustaining of the group & 17 & 57 & 17 & 70 \\
\hline Poor infrastructure & $15 \in V \in T$ & PITE 50 & 15 & 64 \\
\hline Monitoring and Supervision & 15 & 50 & 15 & 64 \\
\hline Poor business management & $5 \mathrm{SN}=2$ & $56=6417$ & 5 & 21 \\
\hline Remuneration \& Motivation & 8 & 0 & 0 & 0 \\
\hline Conflict among the group & 2 & 0 & 0 & 0 \\
\hline
\end{tabular}

*Multiple Responses

Source: Field Survey, October 2012.

Table 9 above revealed that the outstanding challenges of facilitating women empowerment under WDC programme are funding/financing, sustaining training, sustaining of group, poor infrastructure and monitoring/supervision.

\section{Test of Hypotheses}

Ho - Co-operative members to a significant level do not perceive WDC programme as instrumental to their educational advancement.

Table 10: Chi-sqareteston Instrumentality of WDC Programme to Educational Advancement.

\begin{tabular}{|c|c|c|c|}
\hline Value & Observed frequency & Expected Frequency & Residual \\
\hline Not Instrumental & 3 & 10 & -7 \\
\hline Instrumental & 7 & 10 & -3 \\
\hline Very Instrumental & 20 & 10 & 10 \\
\hline Total & $\mathbf{3 0}$ & & \\
\hline
\end{tabular}


International Journal of Trend in Scientific Research and Development (IJTSRD) ISSN: 2456-6470

Table 11: Summary of $X^{2}$ Test Statistics on $\mathrm{Ho}_{2}$

\begin{tabular}{|c|c|}
\hline Chi-square & 15.800 \\
\hline $\mathrm{df}$ & 2 \\
\hline Asymp. Sig. & .000 \\
\hline
\end{tabular}

Tabular $\mathrm{X}^{2}$ Value $=5.99$

Calculated $\mathrm{X}^{2}$-value $=15.8$

Since the calculated $X^{2}$ value (15.8) is greater than the tabular $X^{2}$ value (5.99), we reject the null hypothesis and accept the alternate hypothesis. Therefore, cooperative members to a significant level do perceive WDC program as instrumental to their educational advancement.

Table 12: Chi-sqare test on Access to Extension Services

\begin{tabular}{|c|c|c|c|}
\hline Value & $\begin{array}{c}\text { Observed } \\
\text { N }\end{array}$ & $\begin{array}{c}\text { Expected } \\
\text { N }\end{array}$ & Residual \\
\hline Low Extent & 2 & 7.5 & -5.5 \\
\hline Some extent & 3 & 7.5 & -4.5 \\
\hline Large extent & 16 & 7.5 & 8.5 \\
\hline $\begin{array}{c}\text { Very Large } \\
\text { Extent }\end{array}$ & 9 & 7.5 & 1.5 \\
\hline Total & $\mathbf{3 0}$ & & inernatl \\
\hline
\end{tabular}

Table 13: Summary of $X^{2}$ Test Statistics on $\mathrm{Ho}_{2}$

\begin{tabular}{|c|c|}
\hline & Access to Extension Services \\
\hline Chi-Square(a) & 16.667 \\
\hline Df & 3 \\
\hline Asymp. Sig. & .001 \\
\hline
\end{tabular}

Tabular $\mathrm{X}^{2}$ value $=7.815$

Calculated $X^{2}$ value $=\mathrm{I} 6.67$

Table 13 indicated a chi-square calculated value (16.67) which is greater than the tabular value (7.815) at 3 degree of freedom and 0.05 level of significance. Therefore the null hypothesis is rejected and the alternate hypothesis accepted. It then implies that cooperative members to a significant level regularly access extension services in the WDC programme.

Ho $:$ There is no significant difference in the savings level of co-operatives members before and after joining the WDC program.

Table 14: Monthly Savings Before and After Joining the WDC

\begin{tabular}{|c|c|c|c|c|c|c|}
\hline \multirow{2}{*}{ Savings } & \multicolumn{3}{|c|}{ Before Joining WDC } & \multicolumn{3}{c|}{ After Joining WDC } \\
\cline { 2 - 7 } & N & Mean & Standard Deviation & N & Mean & Standard Deviation \\
\hline 1000 and less & 6 & 2.00 & .000 & - & - & - \\
\hline $1001-3000$ & 17 & 3.35 & .702 & 7 & 1.14 & .378 \\
\hline $3001-5000$ & 5 & 5.20 & .44756 & 10 & 2.00 & .000 \\
\hline $5001-7000$ & 2 & 6.00 & .000 & 5 & 2.00 & .000 \\
\hline $7001-9000$ & - & - & - & 5 & 2.80 & .447 \\
\hline 9001 and above & - & - & - & 3 & 3.67 & .577 \\
\hline Total & $\mathbf{3 0}$ & $\mathbf{3 . 5 7}$ & $\mathbf{1 . 3 0 5}$ & $\mathbf{3 0}$ & $\mathbf{2 . 1 0}$ & $\mathbf{. 1 4 7}$ \\
\hline
\end{tabular}

Table 15: Summary of F-test on $\mathrm{Ho}_{3}$

\begin{tabular}{|c|c|c|c|c|c|}
\hline & Sum of squares & Df & Mean square & F-cal & sig \\
\hline Between Groups & 16.376 & 4 & 4.094 & 44.045 & .000 \\
\hline Within Groups & 2.324 & 25 & 0.013 & & \\
\hline Total & $\mathbf{1 8 . 7 0 0}$ & $\mathbf{2 9}$ & & & \\
\hline
\end{tabular}

F-tab $=2.76$

Since the F-cal (44.045) is greater than the F-tab (2.76) at df of 4 and 25 and significance level of 0.05 , we reject the null hypothesis and accept the alternate hypothesis which is that there is a significant difference in the savings level of co-operative members before and after joining the WDC programme. The result above affirms the difference in the descriptive analysis (table 7) were also the average saving improved after the women joined the WDC programme.

Ho: There is no significant difference in the amount of credit accessed by co-operative members before and after joining the WDC program. 
International Journal of Trend in Scientific Research and Development (IJTSRD) ISSN: 2456-6470

Table16: Summary of Total Credit before and afterJoining WDC

\begin{tabular}{|c|c|c|c|c|c|c|}
\hline \multirow{2}{*}{ Total Credit-Range } & \multicolumn{3}{|c|}{ Before Joining WDC } & \multicolumn{4}{c|}{ After Joining WDC } \\
\cline { 2 - 7 } & $\boldsymbol{N}$ & Mean & Standard Deviation & N & Mean & Standard Deviation \\
\hline 50,000 and less & 18 & 3.67 & 1.085 & 3 & 1.00 & .000 \\
\hline $51,000-100,000$ & 7 & 5.29 & 0.488 & 5 & 1.00 & 0.000 \\
\hline $101,000-150,000$ & 5 & 6.40 & 0.548 & 5 & 1.00 & 0.000 \\
\hline $151,000-200,000$ & - & - & - & 10 & 1.50 & .527 \\
\hline $201,00-250,00$ & - & - & - & 5 & 2.60 & 548 \\
\hline 251,000 and above & - & - & - & 2 & 3.00 & .000 \\
\hline Total & $\mathbf{3 0}$ & $\mathbf{4 . 5 0}$ & $\mathbf{1 . 4 0 8}$ & $\mathbf{3 0}$ & $\mathbf{1 . 5 7}$ & $\mathbf{7 . 7 4}$ \\
\hline
\end{tabular}

Table 17: Summary ofF-test on $\mathrm{Ho}_{4}$

\begin{tabular}{|c|c|c|c|c|c|}
\hline & Sum of squares & $\mathrm{Df}$ & Mean square & F-cal & sig \\
\hline Between Groups & 13.667 & 5 & 2.733 & 17.73 & .000 \\
\hline Within Groups & 3.7 & 24 & 0.154 & & \\
\hline Total & $\mathbf{1 7 . 3 6 7}$ & $\mathbf{2 9}$ & & & \\
\hline
\end{tabular}

F-tab $=2.62$

Since the F-cal (17.73) is greater than the F-tab (2.62), we reject the null hypothesis and accept the alternate hypothesis which is that there is a significant difference in the amount of credit accessed by cooperative members before and after joining the WDC programme. The result affirms earlier descriptive analytical comparisons (Table 8) where the average total credit was higher after the women joined the WDC programme.

\section{SUMMARY, CONCLUSION AND POLICY IMPLICATIONS}

The findings made in the study include that the:

$>$ Roles co-operative play in women empowerment are facilitating skills development, assisting in training of members, easy access to credit facilities and provision of employment opportunities.

$>$ WDC programmes are instrumental to women's educational advancement.

$>$ Extension services facilitated to women cooperative are in the form of agro-extension services, management and financial advice as well as accounting and record keeping education.

$>$ Saving level of women increased when they joined women co-operative in WDC.

$>$ WDC facilitate increased women access to credit.

$>$ Major challenges of facilitating women empowerment under WDC programme are funding/financing, sustaining training, sustaining of group, poor infrastructure and monitoring/supervision.
In this milieu of highly anticipated societal women resurgence, the need to empower Nigerian women cannot be over-emphasized particularly in a democratic society which recognizes the need for individuals to develop their potential to withstand as well as take advantage of the liberalized privatedriven economy. The developing countries of the world still have low gender parity index (GPI) with majority of the women dependent on the men for survival. Perfect gender-equality may not be advocated as women have complementary role to their male counterparts however, there is an imminent need for relative political, economic and social gender-balance; otherwise women will be victims of general degradation in the fast emerging economy.

It is imperative that the public support being provided for women empowerment should be intensified. Women should be encourage to belong to cooperative where sufficient education will be given to them through the help of the government to improve their economic status. More extension services should be provided to them and more financial empowerment should be given to women by the government, Nongovernmental bodies and donor agencies. The catalyzing influence of government aid to women cooperatives in the WDC programme in Anambra State has been successful and empowering. It has made the women more knowledgeable, skilled, creative and economically stable as well as stimulated significant economic development in the rural communities where they reside. 
International Journal of Trend in Scientific Research and Development (IJTSRD) ISSN: 2456-6470

\section{REFERENCES}

1. Agu, S (2007), "Gender Equality, Education and Women Empowerment: The Nigerian Challenge", Multidisciplinary Journal of Research Developemnt, Volume 8, No 2.

2. Akosile A.M.M (2007), "Women as Pillars on Nation Economy Activities of Rural in Six Local Government Area of Ondo state, Nigeria".

3. Borode, M. (2011), "Empowering Women Through Credit Facilities for sustainable Development in the Developing Countries", International Journal of Vocational and Technical and Technical Education, vol. 3 (4).

4. Chukwu, S.C (1990), "Economics of Co-operative Business Enterprise", Marburg consult for selfhelp promotion publishes.

5. Ekesionye E.N and Okolo A.N. (2012), "Women Empowerment and participation in Economic Activities: Indispensible tools for self-reliance and Development of Nigerian society", Educational Research and Review, vol 7 (1)

6. Esere M.O. (2001), "Women Empowerment and it challenges to Gender counseling", Ahamdu Bello University J. Couns Hum. Dev. 1 (1).

7. FGN Report (1996), Vision 2010 Report, Federal Government of Nigeria, Abuja, Nigeria
8. ICA (1995), International Co-operative Alliance Report on the centennial congress of the ICA, Geneva, Switzerland.

9. Longwe, S. (1997), "Education for Women's Empowerment or Schooling for women's subordination". Paper presented at the international seminar-workshop on promoting the Empowerment of women through Adult learning, Chiangmain, Thailand.

10. National Gender Policy (2006) "Federal Ministry of Women Affairs and Social Development".

11. Onugu, C.U. (2006), "Dynamics of Rural-Urban Migration Implications on Development",Journal of policy and development studies. Vol 1

12. Oshodi, J.N and Imasuen O.I (2009), "Women Mobilization in the Empowerment process: A recipe for Rural Development in Edo State, Nigeria", Global Journal of Social Sciences, vol 7 , No 2 .

13. Oyeniyi, O. (2005) Principles and Economics of Co-operative, Standard Publication, Lagos. Women Empowerment in Agricultural, (2012), International food policy research institute, feed the future.

14. Yahaya and Lasiele A (1999), "Women Empowerment in Nigeria: Problem, Prospects and implications for counseling, the counseller, Department of Guidance and counseling, University of Ilorin. 